\title{
The impact of COVID-19 in an ESP course: An unforeseen adaptation to distance teaching
}

\author{
Received: 26/05/2021 | Reviewed: 26/09/2021 | Accepted: 11/01/2022 | Published: 01/03/2022
}

\author{
Paloma LÓPEZ-ZURITA \\ Universidad de Cádiz \\ paloma.lopez@gm.uca.es \\ https://orcid.org/oooo-0oo2-3537-1114
}

\begin{abstract}
The unexpected COVID-19 outbreak in the middle of the school year 2019-2020 and the subsequent declaration of the state of emergency by the Spanish government brought about a dramatic change in classroom structure along with digital innovation at all levels worldwide. Traditional classes inevitably needed to be shifted to an unprecedented as well as unexpected non-face-to-face model that both teachers and students had to use without prior training and which, consequently, required great effort and dedication. This article describes a case study of this adaptation process as it actually ensued in an eminently practical subject. On the other hand, it also examines the students' perception based on an assessment survey on the methodology and activities implemented along the course. The results show the right and wrong choices made in the process, the students' opinion about them together with potential solutions to correct the bad practices identified in the study. Finally, this article shows the extraordinary evolution of the use of new technologies in education as unforeseen one year ago.
\end{abstract}

Keywords: COVID-19; case study; English for Specific Purposes (ESP); online teaching/learning.

\section{L'IMPACTE DE LA COVID-19 EN UN CURS D'ANGLÈS PER A FINS ESPECÍFICS: UNA ADAPTACIÓ IMPREVISTA A L'ENSENYAMENT NO PRESENCIAL}

Resum: La irrupció inesperada de la COVID-19 a mitjans del curs 2019-2020, juntament amb l'establiment de l'estat d'alarma per part del govern espanyol, va provocar una situació mai vista a les aules en tots els nivells educatius i d'abast internacional mundial. Les classes tradicionals van passar obligatòriament a un model no presencial inexistent $i$ imprevist al que tant professorat com alumnat hi van haver de fer front sense formació prèvia. Això va suposar un gran esforç i dedicació per a ambdues parts. Aquest article presenta, així doncs, un estudi de cas de l'adaptació duta a terme en una assignatura eminentment pràctica com és l'anglès aplicat $i$ la percepció d'aquesta de part dels alumnats implicats a través d'un qüestionari d'avaluació de la metodologia i de les activitats realitzades. Els resultats obtinguts ens mostren els encerts $i$ errors comesos, l'opinió sobre aquests, $i$ ens apunta possibles solucions per corregir les pràctiques identificades com a millorables a través de 
noves estratègies d'ensenyament/aprenentatge. Alhora, s'evidencia la gran evolució en l'ús de noves tecnologies en educació que fins fa poc era difícil de concebre.

Paraules clau: COVID-19; estudi de cas; anglès per a fins específics; ensenyament/aprenentatge en línia.

\section{EL IMPACTO DE LA COVID-19 EN UN CURSO DE INGLÉS CON FINES ESPECÍFICOS: UNA ADAPTACIÓN IMPREVISTA A LA ENSEÑANZA NO PRESENCIAL}

Resumen: La irrupción inesperada de la COVID-19 a mitad del curso 2019-2020, junto con el establecimiento del estado de alarma por parte del gobierno español, provocó una situación nunca vista en las aulas a todos los niveles educativos y con un alcance internacional mundial. Las clases tradicionales dieron paso obligatoriamente a un modelo no presencial inexistente e imprevisto que tanto profesorado como alumnado tuvo que afrontar sin experiencia previa y que supuso un gran esfuerzo y dedicación por ambas partes. El presente artículo presenta un estudio de caso de la adaptación llevada a cabo en una asignatura eminentemente práctica como es el inglés aplicado y su percepción por parte de los alumnos implicados, a través de un cuestionario de evaluación de la metodología y actividades realizadas. El resultado obtenido nos muestra los aciertos y errores cometidos, la opinión del alumnado sobre los mismos y nos apunta posibles soluciones para corregir las prácticas identifcadas como mejorables a través de nuevas estrategias de enseñanza/aprendizaje. Al mismo tiempo se evidencia la gran evolución en el uso de nuevas tecnologías en la educación, difícil de imaginar hace poco más de un año.

Palabras clave: COVID-19; estudio de caso; Inglés con Fines Específicos (IFE); enseñanza/aprendizaje en línea.

\section{Introduction}

In early 2020, the outbreak of the new coronavirus strain SARS-CoV-2 (COVID-19) began to spread virulently all over the world. Our fast-paced lifestyle and everyday interaction in the 21 st century led to an abrupt breakout of the disease. On March 14, the Spanish government decreed the quarantine into place as a state of alarm with severe measures subjecting the entire population to complete lockdown. More than 47 million people (INE, 2021) experienced an unprecedented setback in their daily activities under this decree and stayed at their homes. During the lockdown, Spanish society tried to maintain their work-life balance. People had to improvise and learn how to carry on with their gym workouts, cooking classes, concerts, cultural visits, etc. and -most importantly- education at all levels digitally. Virtual learning and teaching spaces were rapidly created in an attempt to continue and successfully finish a school year that had started face-to-face and would have to come to an end online. Overnight, the educational community, from primary education to university were forced to restructure all their teaching content and methodology to adapt to a new non-face-to-face model, in an effort to deliver online teaching with the few tools they had (or were able to use) at that particular moment. Educators started to read about and learn how to implement the so-called online learning, e-learning, web-based learning or distance learning, terms widely used as interchangeable (Tsai \& Machado, 2002), 
a pesar del tiempo y esfuerzo invertidos, como afirma Josep A. Planell, lo hecho estos meses en las universidades presenciales puede haber evitado el colapso, pero no puede llamársele educación online. [despite the time and effort invested, as stated by Josep A. Planell, what has been done these months in face-to-face universities may have prevented the collapse, but it cannot be called online education.] (Menéndez, 2020, p. 130)

Today, more than a year later, it is almost impossible to provide conclusive data on the impact of the disease as cases are still multiplying around the world. There have been millions of infections and deaths and although the new vaccines seem to be largely effective, the virus is still unstoppable in some countries. A large part of the world's population is still subject to either complete or partial lockdown and their recently regained freedoms have been restricted once and again. In an effort to stop the relentless number of infections, there have been strong restrictive measures in place to control the flow and movement within and between countries. In Spain the number of deaths and infections of the tragic days back in March and April 2020 -in which almost a thousand deaths a day were recorded (INE, 2020)- seemed to be under control in the first months of summer. The population at large began to step out of their homes, but the fear of new outbreaks was still on the horizon; unfortunately, this fear was confirmed as the number of new infections started to increase again (Working group for the surveillance and control of COVID-19 in Spain, 2020). After a de-escalation process that seemed to soften the worries of an economic and social disaster, the news began alerting to different towns and cities where the population had to be subject to partial lockdown once more (La Moncloa, 2020). The susceptibility of these communities made a surge in the virus extremely likely. During the following school year (2020-2021) the return to the classroom was still regarded unsafe for public health. This is why the University of Cádiz, as many other educational institutions at all levels worldwide (Sahin \& Shelley, 2020; Trujillo, 2021) chose to use different methods to overcome this health crisis - from fully online teaching to a hybrid model. The worsening of the situation finally led to the second scenario for some months and back to the first one at the end of the school year. This irregular and varying situation might continue to change as the normalization process advances (EEC, 2021). Since teachers need to continuously adapt our teaching approaches and methodologies (Rapanta et al., 2020), we should learn from our mistakes as we move on, taking into account the students' perception all along this process (Baladrón et al., 2020).

\section{Theoretical framework}

Due to the exceptional nature of the situation, there is no theoretical framework compiling any direct precedents or previous studies, with the exception of some pre-pandemic research into the use of the internet and new technologies in language teaching (Fernández, 2018; Stankova, 2019). Nevertheless, while this previous research is of great interest, it was usually conducted in pre-pandemic environments meaning both the teaching staff and students included had previously received specific training in the use of online platforms and other available digital resources. Previous findings are therefore not applicable for this case study. The absence of any theoretical framework and the extraordinary new situation have resulted in new research lines which are intensely developing new studies on the impact of COVID-19 on teaching and learning from different disciplines and perspectives on a global scale. From a sociolinguistic point of view, studies are being conducted to measure the impact of the lockdown on teaching in many countries utilising many different approaches. From a wider scope, in Spain some authors 
called the new 2020 scenario 'emergency non-face-to-face teaching' (Xarles \& Martínez, 2020) as well as 'teaching Rubic', a metaphorical allusion to the different facets and parameters that fit like the famous Rubic cube (Fernández-Gubieda, 2020). There is also growing concern about a rise in the inequality for education opportunities due to the pandemic (Cabrera, 2020), about education rights to all students, including digitally (Cotino, 2020), about how to teach and evaluate in this new reality (Díez \& Gajardo, 2020), etc. Similar worries are also identified in other countries where the pandemic is hitting hard such as Venezuela, where García (2020) highlights the likely loss of interaction with the student. Likewise, in Peru, Velazque, Valenzuela and Murillo (2000) point out the deficiencies this kind of virtual teaching may cause in the training of health science professionals who require more access to laboratories for experiments. In Jordania, Rababah (2020) reports the lack of effective training and accessibility and the inconsistency in teaching styles. Similarly, Indonesia worries about implementing e-learning because a large part of the population do not have reliable internet access, which means that online education is less effective (Zaharah et al., 2020). This also happens in India, where online education is hindered by internet inaccessibility and poor infrastructures and digital skills (Onyema et al., 2020). However, China considers they could turn this emergency into an opportunity to further promote international cooperation and share experiences, knowledge and resources to build a global online education network (Sun et al., 2020).

Another stage in this research includes those studies focused on more specific areas which have also strongly increased and show the world-wide scope of the pandemic, based on the experience gathered during the lockdown. Regarding research on the changes in virtual English learning/teaching, an impressive number of studies from different countries can be mentioned. Most of them are teacher-centered and explore the challenges and opportunities of their virtual teaching experience, as Cárdenas, Nieto-Cruz and Martínez (2021) in Colombia, Hasbi (2020) in Indonesia or Fischer and Rodríguez (2020) in Spain. On the other hand, there are also several studies which reflect the students' perceptions in all this process of adaptation, such as Sepúlveda-Escobar and Morrison (2020) in Chile, Niño, Castellanos-Ramírez and Patrón (2020) in Mexico or Huang, Shi and Yang (2020) in China. In some cases, authors examine the online learning system in their own countries, including the institutional support: Fitria (2020) in Indonesia, or Hernández-Sánchez, López-Gutiérrez and Rocas-Rocas (2020) in Mexico. Other authors such as Alhumaid, Ali, Waheed, Zahid and Habes (2020) in Pakistan, or Rabea and Abdalgane (2020) in Saudi Arabia focus on the logistic, technological, pedagogical, and socioaffective problems that arise when implementing online learning. Simultaneously, some studies include the experiences from a group of countries, namely Azerbaijan, Georgia, Iraq, Nigeria, UK and Ukraine (Doghonadze et al., 2020) or the results gathered from 15 UK universities and colleges - 11 based in England, one in Wales, one in Scotland and two in Northern Ireland (JISC, 2021). In Italy, Luporini (2020) claims the crisis was just a case of accelerating the latent ongoing process of moving teaching practices to online education, regarding this move as an opportunity to develop new teaching experiences.

The field of English for Specific Purposes has also joined this global research trend: Argentina (Waicekawsky et al., 2020): English for Chemistry, Biochemistry and Pharmacy); France (LeCor \& Coutherut (2020): ESP courses at University Paris 8, without specifying the speciality); Indonesia (Iswati,2021): Nursing, Engineering, Pharmacy, Administration, and Accounting); Iran (Saidi \& Afshari, 2021): EAP (English for Academic Purposes) for medical science students); Ukraine (Lytovchenko \& Voronina, 2020): English for STEM (Science, Technology, Engineering, and Mathematics); Uzbekistan (Shokirovich \& Abdijalilovna, 2020): English for Law), etc. 
All these studies show the global impact of the pandemic on every single country in the world.

\section{Objective}

The uncertainty about how the pandemic would evolve made most teachers readapt both their materials and methodology in case the progressive state of de-escalation lasted longer than expected. Therefore, the University of Cádiz planned three possible scenarios for the academic year: (i) traditional classroom teaching; (ii) blended learning (classroom teaching and synchronous online classes in real time, dividing students in two groups, one-half in the classroom and the other half at home) and (iii) online teaching (synchronous or asynchronous). However, the successive waves of the virus forced the institutions to rule out the first option.

The role of Language for Specific Purposes (LSP) teachers has always involved conducting analysis of the students' needs to facilitate the acquisition of specialised content-based language as well as designing and developing courses and materials (Bocanegra \& Basturkmen, 2019). Thus, in order to appropriately plan for different teaching strategies and course design for the above-mentioned situations, our objective was to assess the methodology, activities and tasks carried out in the second semester of 2020 and find out how students had perceived such changes -their digital experience insights regarding effectiveness, usefulness and preferences. The results of such study may offer teaching professionals a tested background in case they have to adapt to new changing scenarios once again. The collected data will provide useful insight on how to move to online learning for future syllabus design, for lack of information is currently a widespread feeling among all the affected teachers.

And in the future we need to think about further developing teachers' technical and pedagogical skills of e-teaching, in order to increase the quality of education, use upto-date teaching methods and be ready for unexpected situations when we may need to move to it totally. (Doghonadze et al., 2020, p. 32)

\section{Methodology}

This case study encompasses both quantitative and qualitative analysis, a combination which is becoming increasingly important in many disciplines (Leech \& Onwuegbuzie, 2009). The data were obtained through observation as well as a survey targeted to students of English Applied to Advertising and Public Relations, an optional six-ECTS credit course in the fourth year of the degree in Advertising and Public Relations at the University of Cádiz. The methodological framework applied for conducting the analysis involved the design of a preliminary questionnaire draft based on the observation of the changes implemented in class. The creation of this draft started off with a deep reflection into our teaching/learning performance and later moved on to the development of a short catalogue of class exercises and tasks. This process, combined with different types of questions to assess both their efficiency and effectiveness, led to the design of a questionnaire we would use as our data-collection instrument. In order to improve and validate this questionnaire, it was piloted three times during its development stage: (i) First, it was peer-reviewed by two other Spanish experienced LSP teachers. (ii) Secondly, piloting was conducted by a native English speaker with experience in education research, to ensure 
language appropriateness. (iii) Finally, a random sample of five students registered in the course verified they understood the questions as intended. The piloting period allowed us to collect feedback about how the questionnaire could work - whether it would actually measure the opinion of students as well as clearly identify how the adaptation to online teaching was running, therefore meeting the goal it had been designed for. It also helped us to make the necessary changes and redesign the final version, checking the comprehensibility of the questions, correcting syntax and spelling, including exercises and tasks, rewording some of these, etc.

In summary, the piloting period helped improve the questionnaire internal consistency. It was initially designed in English, as it was the common working language in class; however, after the collection of feedback from the last piloting group, the Spanish version was also included to ensure Spanish students could express themselves more confidently. Once translated, the first piloting group (LSP teachers) could suggest new changes if necessary before coming up with a final version.

\subsection{Case study and questionnaire design}

Initially, the course included 30 students of which 27 attended class on a regular basis. Six of these students were Erasmus students and one of them returned home. Thus, the group was finally made up of 26 students. The questionnaire was targeted at and sent to them. We received 25 completed questionnaires, so it can be stated that the data obtained and analysed are fairly representative of the perception of the whole group as a case study.

At the end of May, the students received the questionnaire through the Google Forms tool. The questionnaire was anonymous and consisted of 21 questions (Q) divided into three content sections, namely: a) personal data; b) items about the interactive video-conference classes (synchronous teaching) and c) items about the activities carried out and delivered online (asynchronous teaching). Fortunately, the group had the opportunity to attend face-to-face classes in the traditional format for approximately one month before the state of emergency so we could add a fourth section to the questionnaire: d) questions comparing both formats.

The different types of questions (Q) were as follows:

\section{A. Quantitative data:}

i. biodata questions, such as gender, nationality, age, mother tongue, university degree, level of English and previous experience in online foreign language learning (Q1 to Q8);

ii. Q-sort items that asked participants to rank a particular aspect, using a 5-level Likert scale (Q9 to Q15);

iii. closed-response items offering existing possibilities to be ticked as appropriate (Q16, Q17 and Q19);

\section{B. Qualitative data:}

iv. open questions that participants had to answer (Q18 and Q20);

v. critical items that seek participants' feedback (Q21). 
As stated at the beginning of this section, a mixed methods research methodology was adopted to conduct the case study, combining quantitative and qualitative research at the same time, using parallel data gathering by means of the same tool: a survey. Questions in sections (i), (ii) and (iii) correspond to the quantitative analysis and gather a range of numerical data to try to infer the students' thoughts through common descriptive research questions such as "What is more difficult/useful/important? "How much?", "How regularly?" On the other hand, questions in sections (iv), and (v) refer to qualitative data analysis, using content analysis to classify the information from the open questions.

\subsection{Contextual framework: Case study}

The second semester of 2020 started in February. The content and activities for the course in English Applied to Advertising and Public Relations had been previously published on the university virtual campus. The complete course load was 48 hours (four hours per week, $2 \mathrm{~h}$ in the classroom and $2 \mathrm{~h}$ in the language laboratory). The syllabus was task-based and covered the four traditional language skills together with specific communicative approaches. As noted earlier, when the state of emergency was decreed classes had to be resumed online, using materials originally planned for face-to-face teaching. These materials had not been intentionally designed in advance to be delivered fully online, as it is required for a course to be considered an actual online course (Bates, 2008). Initially, students did the exercises as planned, uploaded them to the virtual campus and received feedback within the same week. In these early days what really concerned lecturers and students alike were issues related to accessibility to the Internet, interactions between students and teachers, delivery of lessons, choice among several digital platforms, etc. Additionally, the teacher's workload was significantly enhanced as a result of the individualized and weekly feedback on the exercises. However, this hard work made it possible to supervise each student's work individually. Simultaneously, they began to demand more theoretical written materials as they felt a need to make up for the explanations of 'grammar' originally given in face-to-face classes ${ }^{1}$, even though these types of classes were few and occasional. Thus, the first new action that had to be implemented was to upload grammar theory onto the virtual campus. Students had never requested something like this before, as this kind of materials is easily accessible on the internet and students were used to working on grammar unsupervised. However, it seems they did not like being 'forced' into a 'self-taught' course at that particular point in time. As for speaking practice, students were asked to record themselves in short video presentations about a given topic. This new task, together with the handing in of audio recordings, initially planned for the language lab, was welcomed by students but caused an overload of data files and saturated the official virtual campus. For this particular reason, the course was delivered through Google Classroom. Vocabulary was taught through the completion of a lexicon with the specific terms from each unit using the Moodle activity 'Glossary'. Entries required approval by the teacher before they were unhidden to students. This activity resulted in the compilation of a shared glossary which worked as a collaborative bank of key terms. Simultaneously, the Moodle activity 'Forum' was used. Every week a new forum was posted on the virtual campus where students could give their opinion on current issues. While the forum was optional and served as spontaneous writing practice, it was also highly motivating for the group and enabled participants to have asynchronous discussions. It became a social space for students by providing active communication outside of the strictly academic environment.

\footnotetext{
${ }^{\mathbf{1}}$ It is necessary to clarify that grammar is taught occasionally throughout the course, only if needed as a reminder. Only when/if we identify recurrent, generalised or serious grammar mistakes in the classroom, we include the corresponding explanation and practical exercises related to that specific grammar point.
} 
The course evaluation system also had to be modified. The students' marks were originally based on a final written exam that accounted for $70 \%$ of the students' marks, plus $30 \%$ for active participation in the classroom, completed assignments, presentations, etc. This model was transformed into the following: tasks uploaded (audios, videos, writings, participation in forums, etc.: $30 \%$ (3 points); glossary compilation: $5 \%$ ( 0.5 points); final presentation about an advertising campaign: $10 \%$ (1 point); oral final online exam: $55 \%$ (5.5 points). It is worth mentioning that these results were very satisfactory; in fact, $90 \%$ of the students met the evaluation criteria.

\section{Results and Discussion \\ 4.1 Section one. Personal data}

Section 1 of the survey allows us to identify the basic personal characteristics of the group. It consisted of 21 women (84\%) and four men (16\%); the age range was $18-26$, with a significant majority of $21(24 \%)$ and 22 -year-old $(36 \%)$; most were Spanish $(20=80 \%)$ except for two students from Mexico, one from Italy, one from Ukraine and one from Romania. 23 of them (92\%) were fourth-year students doing their Degree in Advertising and Public Relations or equivalent (Q1 to Q5). The level of English in general was quite good. Fourteen students were $B 1$ level, three B2, three $\mathrm{C} 1$, and five a lower level, A2. These figures were inverted when we asked about their experience in online classes, since only five students $(20 \%)$ had some experience with this methodology in language schools but not in official studies (Q6, Q7 and Q8). Therefore, initially we had a group which were strong in English but almost completely inexperienced in online teaching.

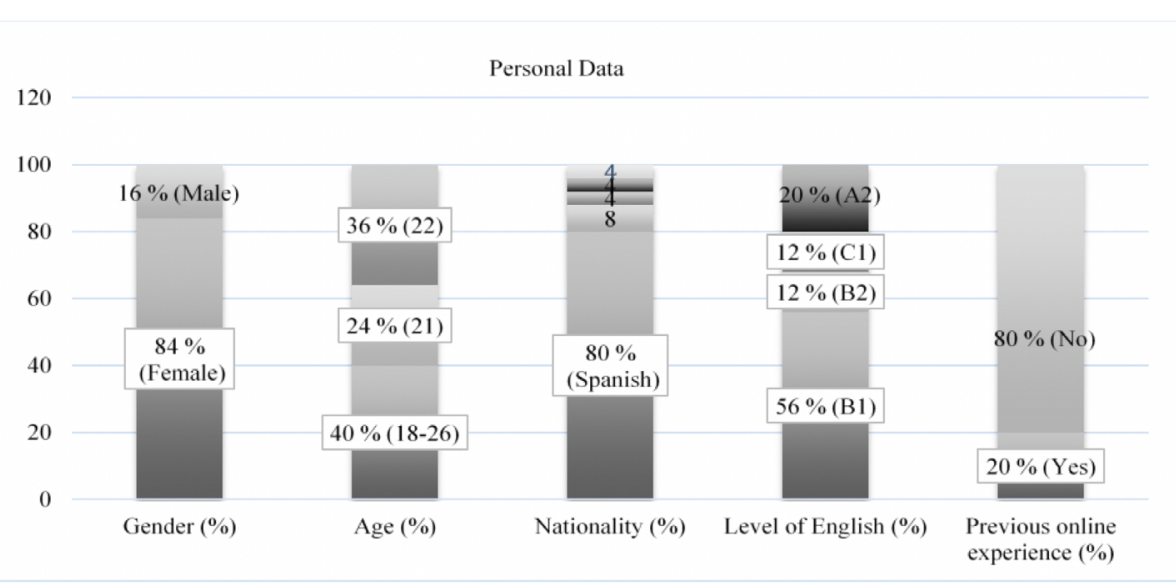

Figure 1. Personal data (questions 1-8).

\subsection{Section 2. Interactive synchronous videoconference classes}

Q9 delved into the level of difficulty of tasks made through synchronous video conferences. This included understanding the teacher, understanding the other students, concentration span in the class, listening and taking notes at the same time, keeping up with the class and, finally, speaking; students considered the most difficult ones 'being able to concentrate in class' $(n=15)$ 
and 'listening and taking notes at the same time' $(n=14)$. The items ranked the easiest were 'understanding the teacher' and 'keeping up with the class' ( $n=22$ and $n=19$, respectively). These answers corroborate what we all suspected: in many cases, home is not a suitable place to 'attend' classes as it may lead to multiple domestic distractions. Despite this, most of them were able to keep the pace of the classes successfully.

Regarding the level of usefulness (Q10), the question consisted of the following items: speaking in English, listening to English, checking exercises, keeping contact with colleagues, keeping personal contact with the teacher to solve questions related to the subject and explanations about specific vocabulary. Fortunately, only one student marked an activity as useless: 'correcting exercises'. The rest considered all the tasks done in class had been somehow useful. We should point out that the item 'keeping personal contact with the teacher to deal directly with issues related to the subject' had 21 responses, although personal contact was also maintained through other channels such as email, forums, customised feedback to individual corrections, etc. The main difference was teachers and students alike could not physically see or listen to each other. As we can observe from these results, the participants highly valued face-to-face interaction. The next two items ranked most useful were 'speaking English' and 'listening to English' ( $n=20$ and $n=18$ cases, respectively). The responses of those who ticked 'checking exercises' differed among students with different levels of English. While it was perceived as useful by some students (usually for those with a lower level), it was not so by some others (usually those with a higher command of the language). Noticeably, the least useful item for everyone was 'keeping contact with the rest of the classmates'. It may seem illogical if we compare it with the top ranked item 'keeping contact with the teacher', but students may have had contact with each other through other means (WhatsApp, Instagram, Twitter, etc.) and therefore thought the interaction among themselves within the course was irrelevant.

\begin{tabular}{|c|c|c|c|}
\hline & Highest Level & Medium Level & Lowest Level \\
\hline $\begin{array}{l}\text { Difficulty of } \\
\text { activities } \\
\text { (Question 9) }\end{array}$ & $\begin{array}{l}\text { 1. Concentrating in class } \\
\text { 2. Listening and taking } \\
\text { notes at the same time }\end{array}$ & $\begin{array}{ll}\text { 3. } & \text { Speaking } \\
\text { 4. } & \text { Understanding } \\
\text { other students }\end{array}$ & $\begin{array}{l}\text { 5. Keeping up with the } \\
\text { class. } \\
\text { 6. Understanding the } \\
\text { teacher }\end{array}$ \\
\hline $\begin{array}{l}\text { Usefulness of } \\
\text { activities } \\
\text { (Question 10) }\end{array}$ & $\begin{array}{l}\text { 1. Personal contact with the } \\
\text { teacher } \\
\text { 2. Speaking in English } \\
\text { 3. Listening to English }\end{array}$ & $\begin{array}{ll}\text { 4. } & \text { Checking exercises } \\
\text { 5. } & \text { Specific vocabulary }\end{array}$ & $\begin{array}{l}\text { 6. maintaining personal } \\
\text { contact with } \\
\text { colleagues }\end{array}$ \\
\hline
\end{tabular}

Table 1. Interactive videoconference classes with the teacher: questions 9 and 10 (Summary).

\subsection{Section 3. Online handed-in activities}

Q11 sought to find out which skills were the most difficult for students in this new online format. Besides the four traditional ones, we included in this section the acquisition of specific Advertising and Public Relations vocabulary, which is very important since it is a case of Applied English. Results showed reading and writing (in that order) were ranked as the easiest ones, followed by the acquisition of vocabulary, which had a neutral response. Oral production (speaking) and comprehension (listening) were highlighted as the two most difficult skills. 
Further delimiting the activities in each skill set, results showed that Q12 confirmed once more that reading and writing activities were ranked as the easiest ('reading and understanding texts', 'writing coherent texts', and 'participating in the forum'). 'Grammar exercises' and making the 'specific glossary' of the subject ranked medium difficulty level. Students seemed to find tasks more difficult when they had to use specific vocabulary in the oral production of their audio or video recordings using correct pronunciation. As for listening comprehension practice, difficulty awareness increased for audio recordings and decreased considerably for video recordings. Again, as we saw in previous questions, the image and visual elements seemed to be essential in understanding the content. These factors directly affected oral production because students found it more difficult to pronounce English words correctly during a video recording than in an audio. Students appear to put a greater effort in the production of video files but less concentrated or focused on sound as when they work with audio files only. This fact is worth of careful consideration, especially when working in the language laboratory, where traditionally tasks focus on audio exercises mainly.

From these results, it is observed how important image is for today's young people. Perhaps influenced by the widespread use of visual applications, such as Instagram or TikTok, they give an utmost importance to this element in communication. This difficulty is implicitly revealed in their answers to Q13, which probes their favourite tasks in the class. The answers were generally neutral. They did not seem to have a favourite activity. The creation of the video recordings, which had been previously ranked as very useful but difficult, did not emerge as the favourite activity. Contrary to expectations, participation in the forums and reading texts, which had been ranked as easy but not extremely useful, were chosen as the activities they preferred. These results seemed to be contradictory and made us think about the reasons why students prefer easy tasks even if these were seen as less useful. One likely explanation could be that students were more concerned about how to cope with the new changes, methods, tools and requirements than about learning itself, at least in the first months of the pandemic.

Q14 examined how students could obtain optimal results when learning English in this new online model. They had to classify the following items in order of relevance: deducing theory after having analysed examples; watching explanatory videos or screen-casting; listening; doing exercises and activities; searching for the information myself; following the instructions given by the teacher during the online classes; reading, writing, speaking and listening as much as I can without stopping too much and, finally, reading, writing, speaking, listening and thinking about it. Results indicated that personal work and the teacher figure are ranked as the most relevant items. 'Reading, writing, speaking and listening and thinking about it' stood out as the best option (10 students chose it as the first option and 7 as the second best). The next best options were 'following the instructions given by the teacher in the online classes' ( 7 and 7 ) and 'doing exercises and activities' ( 6 and 10); that is, they believed their learning was based on active and reflective personal work, but always guided by the teacher figure. These items were followed by 'watching explanatory videos or screen-casting' ( 3 and 7), 'listening' ( 3 and 7), 'reading, writing, speaking and listening as much as I can without stopping too much' (4 and 6) and 'searching for the information myself' ( 1 and 7). Lastly, the least chosen option was 'deducing theory after having analysed examples' ( 3 and 5). From these answers, it may be inferred that students valued self-work and personal reflection but preferred to receive content from the teacher rather than searching for information themselves or deducing theory from practice: 


\begin{tabular}{|c|c|c|c|}
\hline & Highest Level & Medium Level & Lowest Level \\
\hline $\begin{array}{l}\text { Skills Difficulty } \\
\text { (Question 11) }\end{array}$ & $\begin{array}{ll}\text { 1. } & \text { Listening } \\
\text { 2. } & \text { Speaking }\end{array}$ & 3. Vocabulary & $\begin{array}{ll}\text { 4. } & \text { Writing } \\
\text { 5. } & \text { Reading }\end{array}$ \\
\hline $\begin{array}{l}\text { Difficulty of } \\
\text { skills activities } \\
\text { (Question 12) }\end{array}$ & $\begin{array}{l}\text { 1. Pronouncing correctly in } \\
\text { video recordings } \\
\text { 2. Pronouncing correctly in } \\
\text { audio recordings } \\
\text { 3. Understanding audios } \\
\text { 4. Using specific } \\
\text { vocabulary }\end{array}$ & $\begin{array}{ll}\text { 5. Understanding videos } \\
\text { 6. } \\
\text { 7. } & \text { Specific vocabulary } \\
& \text { glossary making }\end{array}$ & $\begin{array}{l}\text { 8. Writing coherent texts } \\
\text { 9. Participating in the } \\
\text { forum } \\
\text { 10. Reading and } \\
\text { understanding texts }\end{array}$ \\
\hline $\begin{array}{l}\text { Favourite } \\
\text { activities } \\
\text { (Question 13) }\end{array}$ & $\begin{array}{l}\text { 1. Participating in the } \\
\text { forum } \\
\text { 2. Reading texts }\end{array}$ & & \\
\hline $\begin{array}{l}\text { Efficacy of } \\
\text { activities for } \\
\text { students } \\
\text { (Question 14) }\end{array}$ & $\begin{array}{l}\text { 1. Reading, writing, } \\
\text { speaking and listening } \\
\text { and thinking about it } \\
\text { 2. Following the } \\
\text { instructions given by the } \\
\text { teacher in the online } \\
\text { classes } \\
\text { 3. Doing exercises and } \\
\text { activities }\end{array}$ & $\begin{array}{l}\text { 4. Watching explanatory } \\
\text { videos or screen- } \\
\text { casting' } \\
\text { 5. Listening } \\
\text { 6. Reading, writing, } \\
\text { speaking and listening } \\
\text { as much as they can } \\
\text { without stopping too } \\
\text { much }\end{array}$ & $\begin{array}{l}\text { 7. Searching for the } \\
\text { information for } \\
\text { themselves } \\
\text { 8. deducing theory after } \\
\text { having analysed } \\
\text { examples }\end{array}$ \\
\hline
\end{tabular}

Table 2. Online handed-in activities: questions 11-14 (Summary).

\subsection{Section 4. Comparison}

When comparing face-to-face and distance teaching in Q15, the preference for the traditional face-to-face model is overwhelming. As shown in the ranking from 'Not at all effective' to 'Extremely effective' most students $(n=21)$ clearly ranked this model the highest in terms of effectiveness. Almost in a similar position are the synchronous videoconference options with the teacher and blended teaching, using digital strategies in tandem with classes on campus. Clearly no one preferred the distance and digital method alone, which was rated as ineffective by 19 of the 25 respondents. Regarding the number of hours devoted to studying English with the new online system (Q17), time increased for almost all the students. Seven of them reported that they spent the same number of hours studying (28\%) but the rest believed they spent more time on the subject than before the outbreak and lockdown (72\%).

No one thought they had spent fewer hours. Otherwise, the numbers of these 'extra' hours vary -the difference ranges between one to five hours a week, although the most significant increase was three or four hours more than usual (Q18). Regardless of the system or methodology used, the content and competencies were ranked as difficult or very difficult by most of the respondents, since 21 students rated the course level of difficulty as 'medium' $(n=5: 20 \%)$, 'quite' $(n=11: 44 \%)$ or 'a lot' $(n=6: 24 \%)(Q 16)$. However, when comparing both systems, the majority answered that distance learning had been more difficult than traditional face-to-face learning $(n=14,56 \%) ; 9$ students (36\%) thought both systems were the same and only 3 students (11\%) found virtual learning easier (Q19). Among those who found it easier, two of them were very fluent in English ( $\mathrm{C} 1$ and B2). 


\begin{tabular}{|c|c|c|c|}
\hline & Highest Level & Medium Level & Lowest Level \\
\hline $\begin{array}{l}\text { Preference } \\
\text { format } \\
\text { (Question 15) }\end{array}$ & $\begin{array}{l}\text { 1. Traditional face-to-face } \\
\text { format }\end{array}$ & $\begin{array}{ll}\text { 2. } & \text { Synchronous digital } \\
\text { teaching } \\
\text { 3. } & \text { Blended teaching }\end{array}$ & $\begin{array}{l}\text { 4. Remote/digital/distance } \\
\text { teaching }\end{array}$ \\
\hline $\begin{array}{l}\text { Course Difficulty } \\
\text { (regardless } \\
\text { format) (Question } \\
\text { 16) }\end{array}$ & $\begin{array}{l}\text { Students who answered 'A } \\
\text { lot': } 6(24 \%)\end{array}$ & $\begin{array}{l}\text { Students who answered } \\
\text { 'Some': } 5(20 \%) \\
-\quad \text { and 'About right': } 11 \\
(44 \%)\end{array}$ & $\begin{array}{l}\text { Students who answered } \\
\text { 'None': } 0 \\
-\quad \text { and 'Little': } 3 \\
(12 \%) \\
\end{array}$ \\
\hline $\begin{array}{l}\text { Number of hours } \\
\text { devoted to online } \\
\text { system (Question } \\
\text { 17) }\end{array}$ & $\begin{array}{lcr}\text { Students } & \text { who } & \text { answered } \\
\text { 'More': } 18(72 \%) & \end{array}$ & $\begin{array}{l}\text { Students who answered } \\
\text { 'Similar': } 7(28 \%)\end{array}$ & $\begin{array}{l}\text { Students who answered } \\
\text { 'Fewer': } 0 .\end{array}$ \\
\hline $\begin{array}{l}\text { Online format } \\
\text { difficulty } \\
\text { (Question } 19)\end{array}$ & $\begin{array}{l}\text { Students who answered 'More } \\
\text { difficult': } 14(56 \%)\end{array}$ & $\begin{array}{l}\text { Students who answered } \\
\text { 'Similar': } 9(36 \%)\end{array}$ & $\begin{array}{l}\text { Students who answered } \\
\text { 'Easier': } 3(11 \%) \text {. }\end{array}$ \\
\hline
\end{tabular}

Table 3. Comparison: questions 15-19 (Summary).

Q20 was open-ended and the students had to give reason for their previous answers. Those who had ranked this system easier either had a high level of English, as mentioned before, or thought it was due to the increase in hours spent on the subject, as may be observed in the following answers: Student a: 'I don't need to spend time to go to University. But I spend more time on homework'; Student b: 'Me ha resultado más fácil porque le he dedicado más tiempo' ['It has been easier for me because I have devoted more time to it']; Student c: 'Es únicamente contestar los ejercicios que son bastante fáciles, no hay actividades que puedan retar como presentaciones, etc. como las había en clase' [We only have to complete the exercises - which are quite easy - there are no challenging activities such as presentations, etc. as there used to be in face-to-face classes]. Those who thought of distance learning as more difficult missed active, direct and face-to-face communication. Student d: 'La clase presencial es mucho más dinámica e interesante. Puedes resolver dudas al momento y es mucho mejor tener contacto con la profesora y todos tus compañeros, sobre todo en una asignatura como esta' [The faceto-face class is much more dynamic and interesting. You can solve queries immediately and it is much better to be in contact with the teacher and all your classmates, especially in a subject like this one]; Student e: 'La interacción es mejor presencial' [Interaction is better if it takes place face-to-face]. Those who had not seen a difference in difficulty expressed it directly: e.g.: Student f: 'Hemos trabajado lo mismo que si lo hubiéramos hecho presencialmente' [We have worked the same as if we had done it in person]; Student g: 'Es igual, porque el aprendizaje es el mismo. Pero la dedicación es mayor, y quizás quite demasiado tiempo para llegar al mismo nivel de aprendizaje' [Both are the same because learning is the same. But the effort put in it is greater and it may take too many hours to reach the same level of learning].

\section{Conclusions}

This article includes a substantial number of current studies on the impact of the pandemic on educational settings published since March 2020 and gives a clear idea of the worldwide impact of the health crisis on the learning-teaching process. It contributes to literature on ESP teaching approaches during the coronavirus lockdown. This case study shows students' perceptions about both methodological models, traditional and online as well as the work of a genuine and spontaneous group that really adjusted to changes as the days went by, faithfully showing the situation that students and teachers had to overcome in the first months of the spread of the virus. Although the findings may only reflect the author's focus on one concrete and specific 
course, similar research could be conducted in other case studies as more data become available, using our proposed methodology and comparing the different findings.

Additionally, our results show the difficulty that all these unforeseen changes in teaching methodology and models above-mentioned entailed for the university as an educational institution as well as for teachers and for students. The situation revealed the inability of the university system to support and bolster online teaching exclusively as it lacks many of the required tools and devices to optimally implement this methodology. Despite the enormous effort made by university staff to facilitate the adaptation process by increasing the capacity of official computer servers and inserting new plugins into the virtual platform, the system continued to be ineffective for such a computer overload throughout those first months of the pandemic. On the other hand, the adaptation process also translated into a remarkable intensification of teachers' commitment since the time necessary to adapt the methods and materials, correct the students' tasks, provide them with weekly feedback and deliver the synchronous classes far exceeded the legally stipulated working hours. This became a liability that revealed the exemplary work commitment of the teaching staff. This new format was also a challenge not only for teachers but also for students as it revealed a lack of familiarity with digital tools and the need of more and/or better Information Technology (IT) training. However, during the second semester of 2019-2020 teachers had to become self-learners themselves. Fortunately, as time went by, lecturers received much more solid training in this area, but those first months were undoubtedly a real challenge. It would have taken years to acquire the same level of skill in the use of new technologies as that achieved just in a few months.

The research described in this article shows that the distance learning model involves a lesser degree of personal interaction between teacher and students. Students preferred the traditional face-to-face format (Q15) and ranked having personal contact with the teachers the most useful activity (Q10). This fact reveals visual contact is essential for students and image works as a crucial tool for optimal communication with (and among) young people. As a result, if the COVID-19 situation draws back again and blended teaching continues to be the norm, it would be advisable to develop synchronous online classes where students could interact as much as possible instead of using a system where asynchronous tasks or screencasts are simply uploaded for students to work on by themselves. Results indicate that even in an increasingly digitised world, personal relationships and direct human contact greatly determine motivation and, consequently, the level of effectiveness of the teaching-learning methods implemented (Q10 and Q14). The request for materials that had not been previously demanded (e.g., grammar theory, as discussed in the previous section) means the students wanted to draw the teacher's attention and prove their dedication; we can gather from their continuous demands to be guided or tutored (Q10) that students did not seem to have a clear goal orientation, which differed from their face-to-face learning experience. They also reported they were acquiring similar levels of knowledge in exchange for more upfront work. This could have resulted in a lack of motivation (Q17-Q19).

In addition, it has also been identified that connectivity and, therefore, the access to classes in some homes was more difficult than in others due to non-academic factors. In some cases, the quality of the internet connectivity in one area was not adequate while other families did not seem to have enough resources and/or devices when several members in the household were teleworking or tele-studying at the same time. The University of Cádiz was aware of this fact and created an extraordinary fund to help these students, either with internet access 
cards or desk computers, when necessary. It was a risky situation as it could result in widening the digital and social breach in society in every educational sector, not only at university level:

The crisis has exposed the many inadequacies and inequities in our school systems -from the broadband and computers needed for online education, through the supportive environments needed to focus on learning, up to the failure to enable local initiative and align resources with needs. (Bates, 2021)

After two academic years of online or blended learning/teaching the pandemic has pushed not only teachers but also students to enhance their digital knowledge. Now all of us have developed digital skills and different platforms are being used. From our initial timid approach to online platforms, we handle several ones simultaneously today -Google Meet, Teams, Zoom, Webex, etc. These are new terms commonly used in our daily lives, something unbelievable two years ago. The pandemic has changed us together with our teaching methods as

The opportunities that digital technologies offer go well beyond a stop-gap solution during the pandemic. Digital technology allows to find entirely new answers to what people learn, how people learn, where people learn and when they learn. It can elevate the role of teachers from imparting knowledge towards working as co-creators of knowledge, as coaches, as mentors and as evaluators (OECD, 2021:5)

\section{References}

Alhumaid, K., Ali, S., Waheed, A., Zahid, E., \& Habes, M. (2020). COVID-19 \& elearning: perceptions \& attitudes of teachers towards e-learning acceptance in the developing countries. Multicultural Education, 6(2), 100-116. https://doi.org/hcfs

Baladrón, A. J., Correyero, B., \& Manchado, B. (2020). Digital transformation of university teaching in communication during the COVID-19 emergency in Spain: an approach from students' perspective. Revista Latina de Comunicación Social, 78, 265-287. https://bit.ly/3q8WeHY

Bates, T. (2008). What do you mean by ...? Online Learning and Distance Education Resources. https://bit.ly/3eL5U4K

Bates, T. (2021). OECD report on the state of school education one year into the pandemic. Online Learning and Distance Education Resources. https://tinyurl.com/y2hkbkwx

Bocanegra, A., \& Basturkmen, H. (2019). Investigating the teacher education needs of experienced ESP teachers in Spanish universities. Ibérica: Revista de la Asociación Europea de Lenguas para Fones Específicos, 38, 127-15o. https://bit.ly/3zGUmt4

Cabrera, L. (2020). Efectos del coronavirus en el sistema de enseñanza: aumenta la desigualdad de oportunidades educativas en España. Revista de Sociología de la Educación-RASE, 13(2), 114-139. https://doi.org/ggws63

Cárdenas, M. L., Nieto-Cruz, M. C., \& Martínez, E. (2021). Editorial: Possible research paths for English language teacher-researchers in the wake of the COVID-19 pandemic. Profile: Issues in Teachers' Professional Development, 23(1), 7-10. https://doi.org/heft

Cotino, L. (2020). La enseñanza digital en serio y el derecho a la educación en tiempos del coronavirus. Revista de Educación y Derecho, 21, 1-29. https://doi.org/gh6c6b

Díez, E., \& Gajardo, K. (2020). Educar y evaluar en tiempos de Coronavirus: la situación en España. Multidisciplinary Journal of Educational Research, 1O(2), 102-134. https://doi.org/gjxkvm 
Doghonadze, N., Aliyev, A., Halawachy, H., Knodel, L., \& Adedoyin, A. S. (2020). The degree of readiness to total distance learning in the face of COVID-19-teachers' view (Case of Azerbaijan, Georgia, Iraq, Nigeria, UK and Ukraine). Journal of Education in Black Sea Region, 5(2), 2-41. https://doi.org/hcfv

Dörnyei, Z. (2013). Questionnaires in second language research. Construction, administration, and processing. Lawrence Erlbaum.

EDC (European Education Center) (2021). Confinement measures in EU countries. Spain (Andalusia). University of Almeria. https://bit.ly/3 $3 \mathrm{FV}_{77} \mathrm{CO}$

Fernández, P. (2018). La enseñanza de lenguas extranjeras a través de las nuevas tecnologías: reflexiones y propuestas. Thélème: Revista Complutense de Estudios Franceses, 33(2), 139-158. https://doi.org/hcfw

Fernández-Gubieda, S. (2020). Docencia Rubic: aprendizajes de la enseñanza universitaria en tiempos de la Covid-19. Eunsa.

Fischer, H., \& Rodríguez, M. C. (2020). La docencia a distancia del inglés: una experiencia didáctica en la universidad. Magister: Revista Miscelánea de Investigación, 32(1), 87-92. https://doi.org/fx4s

Fitria, T. N. (2020). Teaching English through online learning system during Covid-19 pandemic. Pedagogy: Journal of English Language Teaching, 8(2), 138-148. https://doi.org/hcfx

García-García, Ma D. (2020). La docencia desde el hogar. Una alternativa necesaria en tiempos del Covid 19. Polo del Conocimiento: Revista Científico-Profesional, 5(4), 304-324. https://bit.ly/3qchJaV

Hasbi, M. (2020) (Ed.) English teaching practices in Indonesia during Covid-19 crisis. Muhamad Hasbi.

Hernández-Sánchez, S., López-Gutiérrez, J. F., \& Rocas-Rocas, B. (2020). Reflexiones sobre las prácticas sociales y la enseñanza virtual en las escuelas normales en tiempos de COVID-19. Revista Eduscientia. Divulgación de la Ciencia Educativa, 3(6), 86-101. https://bit.ly/32WDdPY

Huang, M., Shi, Y., \& Yang, X. (2020). Emergency remote teaching of English as a foreign language during COVID-19: Perspectives from a university in China. IJERI: International Journal of Educational Research and Innovation, 15, 400-418. https://doi.org/gitdp4

INE (Instituto Nacional de Estadística) (2020). Deaths according to cause of death. Advance JanuaryMay 2019 and 2020. Press Releases. https://bit.ly/32IXecV

INE (Instituto Nacional de Estadística) (2021). Habitantes. https://www.ine.es/index.htm

Iswati, L. (2021). When teaching must go on: ESP teachers' strategies and challenges during COVID-19 Pandemic. Eralingua: Jurnal Pendidikan Bahasa Asing dan Sastra, 5(1), 36-52. https://doi.org/hcfz

JISC (Joint Information Systems Committee) (2021). Student digital experience insights survey 2020/21. https://bit.ly/3eOecJq

La Moncloa. Gobierno de España y Presidencia del Gobierno Español. (2020, April 25). Next Council of Ministers to approve gradual, asymmetrical de-escalation plan with common rules. https://tinyurl.com/yxckygc9

LeCor, G., \& Coutherut, M. (2020). Online courses in times of pandemic: ESP and applied English classes at Université Paris 8. ASp. La revue du GERAS, 78. https://doi.org/hcf2

Leech, N., \& Onwuegbuzie, A. (2009). A typology of mixed methods research designs. Quality and Quantity. International Journal of Methodology, 43, 265-275. https://doi.org/frmp79

Lytovchenko, I., \& Voronina, H. (2020). MOOC as remote ESP learning tool at university in quarantine: focus on students' attitudes, Revista Romaneasca Pentru Educatie Multidimensionala, 12(2Sup1), 70-76. https://doi.org/hef4

Luporini, A. (2020). Implementing an online English linguistics course during the Covid-19 emergency in Italy: teacher's and students' perspectives. ASp. La revue du GERAS, 78. https://doi.org/hcf5 
Menéndez, C. (2020). “iNo es esto, no es esto!”: reflexiones docentes desde una universidad presencial (presuntamente) virtualizada. Magister: Revista Miscelánea de Investigación, 32(1), 129-136. https://doi.org/hcf6

Ministerio de Universidades. (2020, June 10). Recomendaciones del Ministerio de Universidades para adaptar el curso 2020-2021 a una presencialidad adaptada. https://tinyurl.com/y2bcvgak

Niño, S., Castellanos-Ramírez, J. C., \& Patrón, F. (2021). Contrasting the experiences of university students in two educational scenarios: online teaching vs. emergency remote teaching. RED. Revista de Educación a Distancia, 65, 21(7). https://doi.org/hcf7

OECD (2021).The state of school education: one year into the Covid pandemic. OECD. https://doi.org/gnmgb2 Onyema, E., Nwafor, C., Faith, A., \& Sen, S. (2020). Impact of coronavirus pandemic on education. Journal of Education and Practice, 11(13), 108-121. https://doi.org/ghd7sp

Orhan, G., \& Beyhan, Ö. (2020). Teachers'perceptions and teaching experiences on distance education through synchronous video conferencing during Covid-19 pandemic. Social Sciences and Education Research Review, 7(1), 8-44. https://bit.ly/3ncDiGy

Ortega, V. (2020). El reto de mantener las aulas abiertas de manera virtual en tiempos de coronavirus. 7 Congreso Internacional sobre Salud. Universidad Autónoma de Zacatecas, México. https://tinyurl.com/y4e245x9

Rababah, L. (2020). ICT obstacles and challenges faced by English language learners during the coronavirus outbreak in Jordan. International Journal of Linguistics, 12(3), 28-36. https://doi.org/hht4

Rabea, A., \& Abdalgane, M. (2020). Teaching English literacy in the time of COVID-19 pandemic in higher education: a case study in Saudi Qassim University. Multicultural Education, 6(5), 204-215. https://doi.org/hcf9

Rapanta, C., Botturi, L., Goodyear, P., Guárdia, L., \& Koole, M. (2020). Online university teaching during and after the Covid-19 crisis: refocusing teacher presence and learning activity. Postdigital Science and Education, 2, 923-945. https://doi.org/gg4vwp

Sahin, I., \& Shelley, M. (Eds.). (2020). Educational practices during the COVID-19 viral outbreak: International perspectives. ISTES Organization. https://tinyurl.com/y693vu $4 \mathrm{j}$

Saidi, M., \& Afshari, M. (2021). Computer-assisted language learning in English for academic purposes courses: eliciting the instructors' perspectives within the Covid-19 pandemic period. Future of Medical Education Journal, 11(1), 13-17. https://doi.org/hcgb

Shokirovich, T. O., \& Abdijalilovna, Z. D. (2020). Teaching EFL and ESP for Law. Activities and challenges during the covid-19 pandemic in Uzbekistan. Solid State Technology, 63(6), 8318-8325. https://bit.ly/3JH8cAu

Sepulveda-Escobar, P., \& Morrison, A. (2020). Online teaching placement during the COVID-19 pandemic in Chile: challenges and opportunities. European Journal of Teacher Education, 43(4), 587-607. https://doi.org/gneqpf

Sun, L., Tang, Y., \& Zuo, W. (2020). Coronavirus pushes education online. Nature Materials, 19(6), 687-687. https://doi.org/gmmdt9

Tejedor, S., Cervi, L., Tusa, F., \& Parola, A. (2020). Education in times of pandemic: reflections of students and teachers on virtual university education in Spain, Italy, and Ecuador. Revista Latina de Comunicación Social, 78, 1-21. https://doi.org/fp5h

Trujillo, F., (2021). The school year 2020-2021 in Spain during COVID-19: country report. Publications Office of the European Union. https://doi.org/hegc

Stankova, E. (2019). Blended solutions for teaching English for specific purposes. In L. Gómez, A. López \& I. Candel (Eds.), EDULEARN19 Proceedings 11th International Conference on Education and New Learning Technologies (pp. 941-947). IATED Academy. 
Tsai, S., \& Machado, P. (2002). E-learning, online learning, web-based learning, or distance learning: unveiling the ambiguity in current terminology. eLearn Magazine, Education and Technology in Perspective, 7, 3. https://bit.ly/3zlZtPa

Velazque, L., Valenzuela, C.J., \& Murillo, F. (2020). Pandemia COVID-19: repercusiones en la educación universitaria. Odontología Sanmarquina, 23(2), 203-206. https://bit.ly/3K9m3Qj

Waicekawsky, L., Laurenti, L., \& Yuvero, F. (2020). Teaching ESP online during the COVID-19 pandemic: An account of Argentinian students on this teaching modality. SHS Web of Conferences, 88. https://doi.org/hegd

Working group for the surveillance and control of COVID-19 in Spain. (2020) The first wave of the COVID-19 pandemic in Spain. Characterisation of cases and risk factors for severe outcomes, as at 27 April 2020. Euro Surveillance Journal, 25(50). https://tinyurl.com/y3yeerbw

Xarles, G., \& Martínez, P. (2020). Docencia no presencial de emergencia: un programa de ayuda de emergencia en el ámbito de la educación superior en tiempos de la COVID-19. Análisis Carolina, 32, 1-12. https://doi.org/hegf

Zaharah, Z., Kirilova, G. I., \& Windarti, A. (2020). Impact of corona virus outbreak towards teaching and learning activities in Indonesia. SALAM: Jurnal Sosial dan Budaya Syar-I, 7(3), $269-282$. https://doi.org/hegg 